\title{
Polymorphisms of $\beta$-defensin genes in Valle del Belice dairy sheep
}

\author{
Giuseppina Monteleone • Davide Calascibetta • \\ Mariangela Scaturro $\cdot$ Paola Galluzzo $\cdot$ Marisa Palmeri • \\ Valentina Riggio $\cdot$ Baldassare Portolano
}

Received: 14 October 2010/ Accepted: 26 February 2011

(C) Springer Science+Business Media B.V. 2011

\begin{abstract}
The aim of this work was to study $\beta$-defensin 1 $(S B D 1)$ and $\beta$-defensin 2 (SBD2) genes in Valle del Belice dairy sheep in order to identify polymorphisms that can be utilized as markers of the analyzed genes, and search for the functional effects and roles of the identified polymorphisms (variation of the amino acid sequence of the protein and stability of mRNA molecule). The study was conducted on 300 randomly selected animals belonging to four flocks. A total of seven SNPs were identified, two in $S B D 1$ and five in $S B D 2$. The two SNPs identified in SBD2 coding region, at position 1659 and position 1667, were nonsynonymous, leading to amino acid changes in the protein product. Nevertheless, the functional effects predicted by the two SNPs demonstrated that amino acid substitutions may not have effect on $\beta$-defensin 2 protein function. Moreover, we demonstrated that SBD2 mutant sequence shows changes in mRNA secondary structure. These results suggest that identified SNPs could play a role in the modulation of the immune response.
\end{abstract}

Keywords $\beta$-Defensin $\cdot$ SNPs $\cdot$ Sheep $\cdot$ Valle del Belice

Giuseppina Monteleone and Davide Calascibetta equally contributed to this work.

G. Monteleone $(\bowtie) \cdot$ D. Calascibetta $\cdot$ P. Galluzzo .

V. Riggio $\cdot$ B. Portolano

Dipartimento DEMETRA-Sezione Produzioni Animali,

Università di Palermo, Viale delle Scienze Parco d'Orleans,

90128 Palermo, Italy

e-mail: giusi.monteleone@senfimizo.unipa.it

D. Calascibetta $\cdot$ M. Scaturro $\cdot$ M. Palmeri

Consorzio Regionale di Ricerca Bioevoluzione Sicilia, c/o Dipartimento DEMETRA-Sezione Produzioni Animali, Università di Palermo, Viale delle Scienze Parco d'Orleans, 90128 Palermo, Italy

\author{
Abbreviations \\ SBD1 $\beta$-Defensin 1 gene \\ SBD2 $\beta$-Defensin 2 gene \\ AMPs Antimicrobial peptides family \\ SCC Somatic cell count
}

\section{Introduction}

Defensins are a family of small peptides belonging to the antimicrobial peptides (AMPs) group. They represent the major family of AMPs found in invertebrates, vertebrates and plants [1-5]. The defensin family includes peptides ranging from 18 to 45 amino acids, which contain cysteines, have three intramolecular disulfide bonds, cationic net charge due to arginine and lysine residues, and tertiary structures dominated by $\beta$-sheets [6, 7]. Defensins are classified into $\alpha$-, $\beta$-, and $\theta$ - based on structure, size, and disulfide bonds pattern [7, 8]. These peptides are involved in the innate immunity mechanisms and act directly against bacteria, viruses, and fungi, due to their bactericidal and cytotoxic activity [4]. Moreover, they have been suggested as effector molecules in host defense, interacting with many target cells and tissues [9]. Defensins have been reported to promote secondary responses that may be critical in the regulation of acute inflammation, recruitment of adaptive immune cells, angiogenesis, and wound healing [10]. Defensins may be therefore considered as link molecules between the innate and the acquired immune response [11].

The genes, encoding for defensins are arranged in clusters $[12,13]$ and expressed in epithelial cells lining various organs $[14,15]$ and in leukocytes [16].

In recent years, $\beta$-defensin genes have been studied in several domestic species such as cattle, pig, and goat, due 
to their important role in the immune response. To date, 13 neutrophils and two epithelial (i.e., the tracheal antimicrobial peptide (TAP) and the lingual antimicrobial peptide (LAP)) $\beta$-defensins have been described in cattle [16-18]. Moreover, Cormican et al. [19] recently reported a novel group of bovine $\beta$-defensins. In pigs, $\beta$-defensin 1 has been characterized by Shi et al. [20]. Sang et al. [21] have also reported the identification and initial characterization of 11 novel $\beta$-defensins in pigs. In goats, the precursors for $\beta$-defensin 1 and $\beta$-defensin 2 have been characterized by Zhao et al. [22]. Sharma et al. [23] have also cloned and characterized the mRNA sequence of a gene encoding the caprine LAP.

In sheep, only two $\beta$-defensin genes have been described so far: $\beta$-defensin 1 (SBD1) and $\beta$-defensin 2 (SBD2). Both genes have been mapped on chromosome 26 and consist of two exons and one intron of approximately 1,500 bp [24]. The first 58 bp exon encodes the signal sequence and the second $296 \mathrm{bp}$ exon encodes the pro-peptide and the mature peptide [25]. There are several studies published on $\beta$-defensin polymorphisms in human and cattle; which have been generally associated to diseases [26, 27] and production traits [28-30]. However, literature does not report results on $\beta$-defensin polymorphisms in sheep. Therefore, the aim of this work was to study SBDl and $S B D 2$ in Valle del Belice dairy sheep in order to identify polymorphisms that can be utilized as markers of the analyzed genes, and search for the functional effects and roles of the identified polymorphisms (variation of the amino acid sequence of the protein and stability of mRNA molecule).

\section{Materials and methods}

Animals and sample collection

A total of 300 samples of Valle del Belice dairy sheep randomly chosen from four flocks were included in the analysis. Blood samples from each animal were collected, and genomic DNA was extracted from buffy coat using a salting out DNA isolation method [31].

\section{$\beta$-Defensin genes amplification}

Four specific primer pairs were designed to amplify $S B D 1$ and SBD2 exons on the basis of the sequences available in the GenBank database (Acc. no. U75250 and U75251, respectively). Primer sequences, size of amplified fragments, and annealing temperatures for SBD1 and SBD2 are reported in Table 1 . PCR reactions were performed in a thermal cycler GeneAmp PCR system 9700 (Applied Biosystems, Foster City, CA, USA) in a final volume of $20 \mu \mathrm{l}$ containing $50 \mathrm{ng}$ of genomic DNA, $10 \mu \mathrm{M}$ of each primer and $2 \times$ PCR Master Mix (Fermentas, Burlington, ON, Canada). Thermal cycling conditions were: $94^{\circ} \mathrm{C}$ for $3 \mathrm{~min}, 35$ cycles of $94^{\circ} \mathrm{C}$ for $30 \mathrm{~s}, 62-68^{\circ} \mathrm{C}$ for $30 \mathrm{~s}, 72^{\circ} \mathrm{C}$ for $1 \mathrm{~min}$, and a final extension of $72^{\circ} \mathrm{C}$ for $5 \mathrm{~min}$. PCR products were checked by electrophoresis on $2 \%$ agarose gel stained with ethidium bromide.

\section{Sequencing of $\beta$-defensin genes}

In total, 100 out of the 300 sheep sampled, were analyzed by direct sequencing, in an ABI PRISM 3130xl Genetic Analyzer (Applied Biosystems, Foster City, CA, USA). PCR products of $S B D 1$ and SBD2 were purified using Exonuclease I and Shrimp Alkaline Phosphatase according to manufacturer's protocol (Fermentas, Burlington, ON, Canada). DNA sequencing reaction was carried out using BigDye Terminator v3.1 Cycle Sequencing Kit (Applied Biosystems, Foster City, CA, USA) with the same primers used in the PCR reaction. Cycle sequencing reaction was performed according to manufacturer's instructions following Ethanol/EDTA/Sodium Acetate precipitation.

Single nucleotide primer extension assay

A single nucleotide primer extension assay was set up to analyze the remaining 200 sheep. Seven specific primers
Table 1 Primer sequence, amplified fragments, and annealing temperature for $S B D 1$ and $S B D 2$

\begin{tabular}{|c|c|c|c|c|}
\hline Gene & Region & Primer sequence $5^{\prime}-3^{\prime}$ & $\begin{array}{l}\text { Amplified } \\
\text { fragment (bp) }\end{array}$ & $\begin{array}{l}\text { Annealing } \\
\text { temperature }\left({ }^{\circ} \mathrm{C}\right)\end{array}$ \\
\hline \multirow[t]{4}{*}{$S B D 1$} & Exon1 & Fw-CAGCCTCTTCTCCAGCATCA & 282 & 66 \\
\hline & & Rev-GAATTTTGCAGGACGGTTCT & & \\
\hline & Exon2 & Fw-ATTGTCATGAAGCCGTGTCCG & 423 & 68 \\
\hline & & Rev-ATTCACCTGGGATCAGACACCACA & & \\
\hline \multirow[t]{4}{*}{$S B D 2$} & Exon1 & Fw-CAGCCTCTTCTCCAGCATCA & 279 & 62 \\
\hline & & Rev-AAATTTTGCAGGACAGTTCT & & \\
\hline & Exon2 & Fw-GTTGTCATGAAGCCGTGTCCA & 392 & 66 \\
\hline & & Rev-ACCTCAATGACCAGTGGGCAAGAT & & \\
\hline
\end{tabular}


Table 2 Primer sequences, length, and final concentration $(\mu \mathrm{M})$ for the single nucleotide primer extension assay

\begin{tabular}{|c|c|c|c|}
\hline SNP position & Primer sequence & Length (bp) & $(\mu \mathrm{M})$ \\
\hline SBD1-1747 & 5'-CAGAAGTCTAAGACGCGGCC- $3^{\prime}$ & 20 & 0.09 \\
\hline$S B D 1-1757$ & $3^{\prime}$-CCTCATTCTTTGACGCGGGA(A) $)_{5} 5^{\prime}$ & 25 & 0.09 \\
\hline$S B D 2-89$ & $5^{\prime}-(\mathrm{A})_{15} \mathrm{CATCACCTACTCCTCGTGCT-3'}^{\prime}$ & 35 & 1.5 \\
\hline$S B D 2-1659$ & $5^{\prime}-(\mathrm{T})_{10}$ AGGAATCTGTGTGCTGACCA-3' & 30 & 0.2 \\
\hline$S B D 2-1667$ & $3^{\prime}$-CCTGATACTCTGTCTAACCGTGGA(T) $)_{21}-5^{\prime}$ & 45 & 0.8 \\
\hline$S B D 2-1750$ & $5^{\prime}-(\mathrm{T})_{20}$ CAGAAGTCTAAGACGCGGCC- $3^{\prime}$ & 40 & 0.2 \\
\hline$S B D 2-1761$ & $3^{\prime}$-CTCAGTCTTTGACGCAGGAA $(\mathrm{T})_{30}-5^{\prime}$ & 50 & 1 \\
\hline
\end{tabular}

SBD1_Exon 2

Fig. 1 Primers design for single nucleotide primer extension assay. Larger letters indicate SNPs. Underlined nucleotides indicate primers with tails of variable length, used for polymorphisms detection

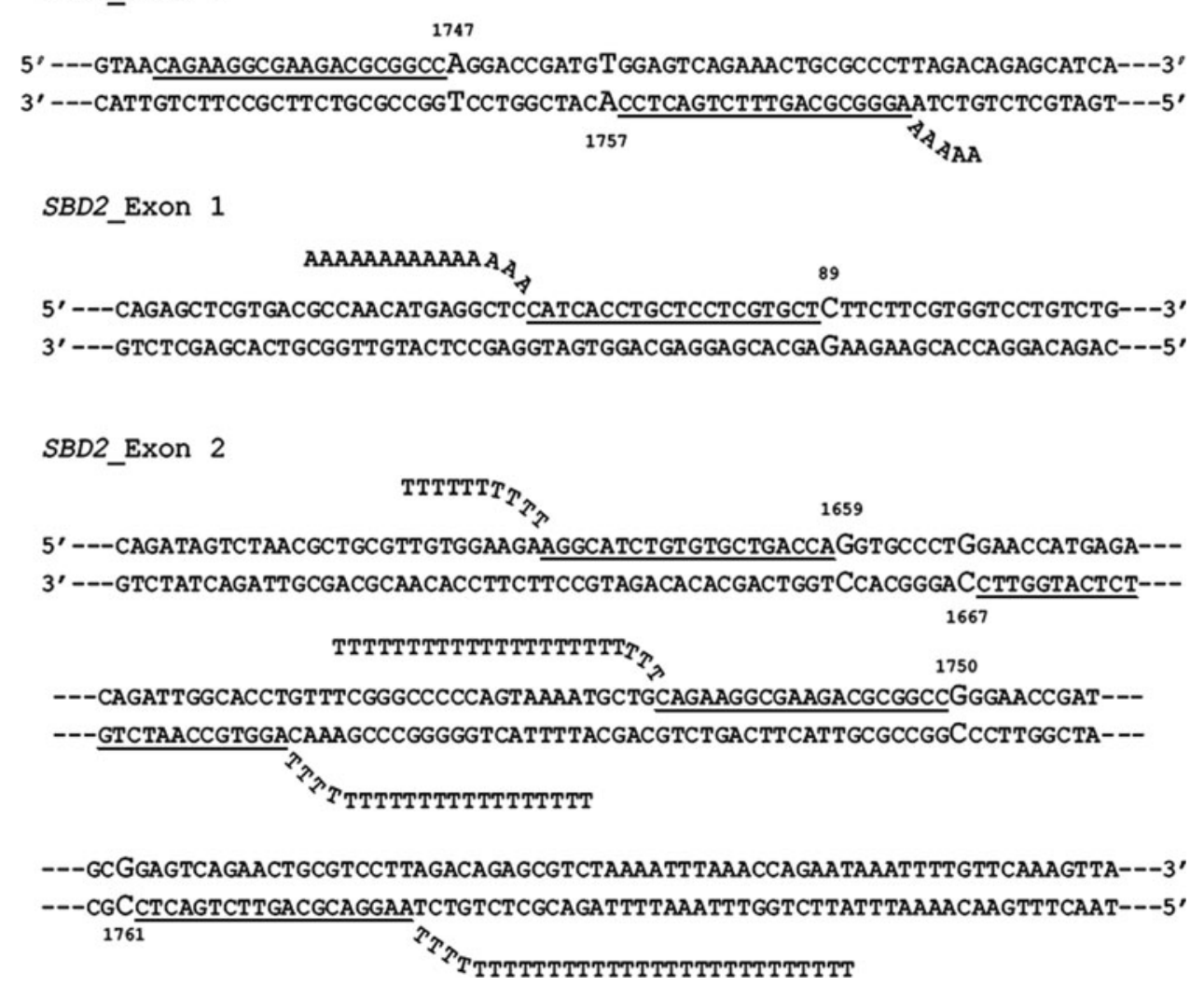

were designed: two for $S B D 1$ and five for $S B D 2$. The primers sequence, length, and concentration used in the reaction are reported in Table 2. Primer sequences were chosen in order to have the appropriate length and melting temperature. Primers were designed complementary to the negative (-) DNA strand when the positive (+) DNA strand was difficult to assay (Fig. 1). Poly(dT) or poly(dA) of variable length were added at the $5^{\prime}$ end of the primers in order to modify the length, and to avoid overlapping of peaks in the electropherograms obtained by capillary electrophoresis. Following template amplification, $15 \mu \mathrm{l}$ of the PCR product were incubated at $37^{\circ} \mathrm{C}$ for $1 \mathrm{~h}$ with $2 \mathrm{U}$ of Exonuclease I and $5 \mathrm{U}$ of Shrimp Alkaline Phosphatase (Fermentas, Burlington, ON, Canada). Two multiplex primer extension reactions were used: the first one for genotyping SNPs in $S B D 1$ exon 2 and in $S B D 2$ exon 1, and the second one for genotyping SNPs in SBD2 exon 2. Single nucleotide primer extension reaction was carried out in $5 \mu \mathrm{l}$ reaction mixture containing $2.5 \mu \mathrm{l}$ of SNaPshot Multiplex Ready Reaction Mix (Applied Biosystems, Foster City, CA, USA), $0.5 \mu$ l of primers mix, $0.5 \mu$ of deionized water and $1.5 \mu \mathrm{l}$ of pooled PCR products previously purified. Thermal cycling conditions for extension reactions were: 25 cycles of $96^{\circ} \mathrm{C}$ for $10 \mathrm{~s}, 55^{\circ} \mathrm{C}$ for $5 \mathrm{~s}$, and $60^{\circ} \mathrm{C}$ 
for $30 \mathrm{~s}$ using a GeneAmp PCR system 9700 (Applied Biosystems, Foster City, CA, USA). To remove unincorporated labeled ddNTPs, $0.5 \mathrm{U}$ of Shrimp Alkaline Phosphatase (Fermentas, Burlington, ON, Canada) were added to the primer extension product and incubated at $37^{\circ} \mathrm{C}$ for $1 \mathrm{~h}$ followed by $75^{\circ} \mathrm{C}$ for $15 \mathrm{~min}$. Finally, $2 \mu \mathrm{l}$ of the primer extension product mixed with $7.5 \mu \mathrm{l}$ of $\mathrm{Hi}-\mathrm{Di}$ Formamide and $0.5 \mu 1$ of GeneScan 120 LIZ Size Standard (Applied Biosystems, Foster City, CA, USA) were denaturated for $5 \mathrm{~min}$ at $95^{\circ} \mathrm{C}$. Capillary electrophoresis was performed in an ABI PRISM 3130xl Genetic Analyzer (Applied Biosystems, Foster City, CA, USA).

\section{Bioinformatics analyses}

SeqScape v2.5 software (Applied Biosystems, Foster City, CA, USA) was used to analyze the nucleotide sequences, and the Clustal W software [32] to align the sequences. Results of the primer extension assay were analyzed by GeneMapper v3.7 software (Applied Biosystems, Foster City, CA, USA). GENEPOP v4.0 software [33] was used to calculate genotypic frequencies. The evaluation of HardyWeinberg equilibrium was carried out with chi-square analysis from the HWE software program (Linkage Utility Programs, Rockefeller University, New York, NY, USA). Estimation of the likelihood of the nonsynonymous coding SNPs to cause a functional impact on the protein was evaluated with PANTHER (Protein ANalysis THrough Evolutionary Relationships) software [34]. This software calculates the subPSEC (substitution Position-Specific Evolutionary Conservation) and a probability $\left(\mathrm{P}_{\text {deleterius}}\right)$ score based on an alignment of evolutionarily related proteins. The probability that a given variant will cause a deleterious effect on protein function is estimated by $\mathrm{P}_{\text {deleterious, }}$, such that a subPSEC score of -3 corresponds to a $\mathrm{P}_{\text {deleterious }}$ of 0.5. SIFT (Sorting Intolerant From Tolerant) software [35] was used to predict whether the amino acid substitution affects protein function based on sequence homology and the physical properties of amino acids. SIFT is a multistep procedure in the sense that, given a protein sequence, the software firstly searches for and chooses similar sequences, then makes an alignment of these sequences, and finally calculates scores based on the amino acids appearing at each position in the alignment. The amino acid substitution is predicted as deleterious if the score is $\leq 0.05$, and tolerated if the score is $>0.05$. The analysis was carried out using the default value of median conservation of sequences.

The RNAstructure v4.6 software was used for the prediction and analysis of SBDs mRNA secondary structure [36], using default options. This software uses a structure prediction algorithm and the most current thermodynamic parameters to predict the secondary structure based on
RNA sequence. For this analysis, wild type and $3^{\prime}$-UTR mutated $\beta$-defensin mRNA sequences were used.

\section{Results}

SNPs identification and genotypic frequencies

Alignment and analysis of $S B D 1$ and $S B D 2$ sequences revealed the presence of 7 polymorphic sites. All point mutations were SNPs. The SNPs were submitted to the Single Nucleotide Polymorphism database-dbSNP(http://www.ncbi.nlm.nih.gov/projects/SNP/). No SNPs were found in the $S B D 1$ exon 1, whereas two SNPs were found in the exon 2: a transition $\mathrm{A} \rightarrow \mathrm{G}$ at position 1747 (RefSNP number 119102887) and a transition $\mathrm{T} \rightarrow \mathrm{C}$ at position 1757 (RefSNP number 119102888) in the $3^{\prime}$-UTR. Mutation at position 1747 creates a cutting site for HpaII restriction enzyme. Our results showed that all individuals presenting the $\mathrm{A} \rightarrow \mathrm{G}$ change at position 1747, presented the $\mathrm{T} \rightarrow \mathrm{C}$ change at position 1757 as well; suggesting that SNP alleles were tightly linked. The tight linkage between the two mutation sites was also confirmed by primer extension. Based on these results, sheep were only genotyped for the SNP at position 1757.

In $S B D 2$, SNPs were found in both exons. A transition $\mathrm{C} \rightarrow \mathrm{T}$, located at position 89 in the coding region (RefSNP number 119102892) was the only SNP found in the exon 1 . However, this synonymous substitution does not change the amino acid residue within the protein sequence. The four SNPs detected in the exon 2 were all transitions $\mathrm{G} \rightarrow \mathrm{A}$. The $\mathrm{G} \rightarrow \mathrm{A}$ at position 1659 (RefSNP number 119102893) determines an amino acid change $\mathrm{Arg}^{42} \rightarrow$ Lys $^{42}$, whereas the one at position 1667 (RefSNP number 119102889) causes the switch Gly ${ }^{45} \rightarrow \mathrm{Arg}^{45}$. The SNPs at position 1750 (RefSNP number 119102890) and 1761 (RefSNP number 119102891) were located in the $3^{\prime}$-UTR. The substitution at position 1750 disrupts a cutting site for HpaII restriction enzyme.

Genotypic frequencies for each SNP are reported in Table 3. As expected, SNPs in SBD1 showed the same frequency in wild type, heterozygote, and mutated homozygote condition. Among the seven SNPs, those at positions 89, 1667, 1750, and 1761 were not found in mutated homozygote condition, whereas the other SNPs (i.e., 1747 and 1757 in $S B D 1$ and 1659 in SBD2) occurred with low frequency in this condition. The $S B D 2$ genotypes at positions 89,1667 , and 1761 occurred more frequently in wild type condition. Moreover, mutation at position 1667 occurred more rarely compared to the others, as it is characterized by the lowest frequency value in heterozygote condition (0.03). All SNPs did not fit Hardy-Weinberg equilibrium. 
Table 3 SNPs positions in $S B D 1$ and $S B D 2$ and genotypic frequencies

\begin{tabular}{lllll}
\hline Gene & SNP position & \multicolumn{3}{c}{ Genotypic frequencies } \\
\cline { 3 - 5 } & & Wild type & Heterozygote & Mutated homozygote \\
\hline SBD1 & $1747 \mathrm{~A} \rightarrow \mathrm{G}$ & AA $(0.78)$ & GA $(0.16)$ & GG $(0.06)$ \\
& $1757 \mathrm{~T} \rightarrow \mathrm{C}$ & TT $(0.78)$ & TC $(0.16)$ & CC $(0.06)$ \\
SBD2 & $89 \mathrm{C} \rightarrow \mathrm{T}$ & CC $(0.72)$ & CT $(0.28)$ & TT $(0)$ \\
& $1659 \mathrm{G} \rightarrow \mathrm{A}$ & GG $(0.39)$ & GA $(0.56)$ & AA $(0.05)$ \\
& $1667 \mathrm{G} \rightarrow \mathrm{A}$ & GG $(0.97)$ & GA $(0.03)$ & AA $(0)$ \\
& $1750 \mathrm{G} \rightarrow \mathrm{A}$ & GG $(0.49)$ & GA $(0.51)$ & AA $(0)$ \\
& $1761 \mathrm{G} \rightarrow \mathrm{A}$ & GG $(0.83)$ & GA $(0.17)$ & AA $(0)$ \\
\hline
\end{tabular}

In silico SNPs analyses

The PANTHER and SIFT software's were used to predict the functional effects of SNPs determining an amino acid change in the sheep $\beta$-defensin 2 protein. The predictions performed by PANTHER gave the subPSEC scores of $-1.81977\left(\mathrm{P}_{\text {deleterious }}=0.23501\right)$ and $-2.63999\left(\mathrm{P}_{\text {deleterious }}\right.$ $=0.41096$ ) for the amino acid change at position 42 and 45 , respectively. Both values were lower than the cut-off value $\left(\mathrm{P}_{\text {deleterious }}=0.5\right)$. The output of SIFT software for SBD2 substitutions showed that they are to be tolerated with a score of 0.20 and 0.24 respectively; indicating that the aforementioned mutations may not have a functional effect.

The SNPs located in the $3^{\prime}$-UTRs (i.e., at position 1747 and 1757 in SBD1 and at position 1750 and 1761 in SBD2) were analyzed with RNAstructure software to determine their influence on the SBDs mRNA structure. The results obtained after comparing the wild type (Fig. 2a) and mutated SBD2 (Fig. 2b, c, and d) sequences show that the SNPs at position 1750 and 1761 change the tridimensional mRNA secondary conformation (Fig. $2 b$ and c, respectively). However, when the two mutations are both present (Fig. 2d), the mRNA folds as well as when only the SNP at position 1750 is present. It seems, therefore, that this mutation has a greater effect on the RNA folding. The SNPs found in the sequence of $S B D 1$ did not affect mRNA shape.

\section{Discussion}

Recent studies have indicated that $\beta$-defensins play an important role in innate immune responses showing an immunomodulatory activity as well [37]. Due to their important biological function the nucleotide sequences which encode for these peptides were well characterized in mammals. Moreover, attention was recently focused on the alterations in overall charge, length, and sequence of these peptides associated with variations in the nucleotide sequence [38, 39]. $\beta$-defensin genes have been shown to present high polymorphism in the human [26, 27, 40] and bovine [28-30, 41] sequences. Nevertheless, current knowledge regarding $\beta$-defensin polymorphism in sheep is limited. In cattle, Ryniewicz et al. [28] reported that polymorphisms of defensin genes could be used as markers for udder health traits and susceptibility to inflammations. Moreover, Bagnicka et al. [30] showed that the polymorphism of $\beta 4$-defensin gene might be used in breeding programs as molecular marker in the selection of dairy cattle with increased resistance to mammary gland infection. The inflammation of the mammary gland is indeed one of the most common health problems affecting dairy species [42]. Nevertheless, work involving the association of $\beta$-defensin SNPs identified in this study with somatic cell count (SCC), as indirect indicator of mastitis is required to resolve the applicability of the aforementioned SNPs in marker assisted selection for mastitis resistance in Valle del Belice dairy sheep.

The SNP identified in SBD2 exon 1 does not cause any change in the amino acid sequence. Nevertheless, several studies have shown that mutations which are predicted to be translationally silent can alter gene expression by influencing splicing accuracy/efficiency or codon biasness $[43,44]$.

The two missense mutations identified in SBD2 have been reported previously by Luenser et al. [25] in two species belonging to the Caprini tribe. The first of these substitutions ( $\mathrm{Arg}^{42} \rightarrow \mathrm{Lys}^{42}$ ) was described in Ovis ammon (Argali sheep), and is located in a site which presents a moderate conservation level and determines the change of a residue with similar physico-chemical features (both amino acids involved in the substitution are basic). The second mutation $\left(\mathrm{Gly}^{45} \rightarrow \mathrm{Arg}^{45}\right.$ ), detected in the Ovis orientalis cycloceros (Afghan urial), is associated to the switch from nonpolar to polar amino acid resulting in the substitution of residues with different features. This change could have an effect on the interaction between the protein and the host membrane; indeed the physical driving force behind antibacterial activity of these antimicrobial molecules is known to involve the spatial arrangement of polar and hydrophobic residues [45]. The similar mutation 
(a)

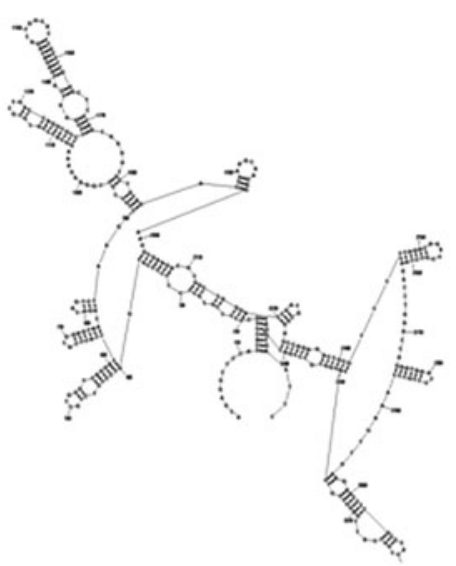

(b)

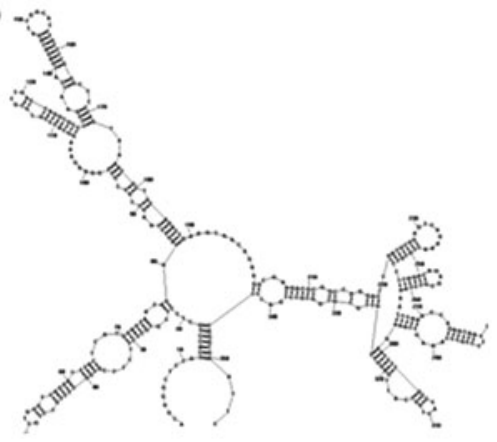

(c)

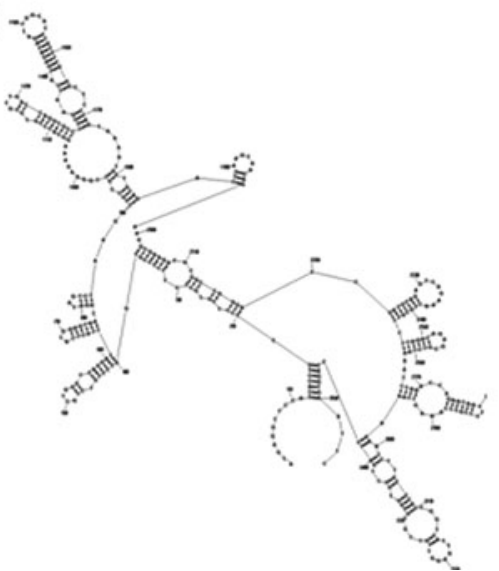

(d)

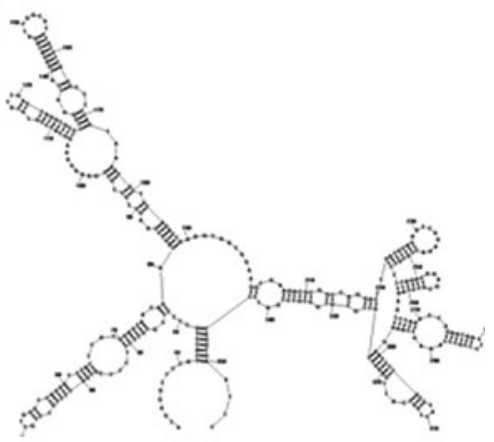

Fig. 2 SBD2 tridimensional mRNA secondary structure. Structure of the wild type (a) and mutated mRNA in relation to the 3'-UTR SNP at position $1750(\mathbf{b}), 1761(\mathbf{c})$, and 1750 and $1761(\mathbf{d})$

profile observed in the Valle del Belice breed in this study, most likely reflects a recent common ancestry for the two Asian breeds and Ovis aries species. These results are in agreement with the theory based on the existence of a common ancestral $\beta$-defensin gene, which after duplication became subject to lineage-specific evolution by mutation and natural selection $[12,46]$.

The analysis with PANTHER and SIFT software's showed that the coding SNPs in SBD2 do not affect protein function, as the amino acids involved in the substitution at position 42 have the same physical and chemical features. This change, therefore, does not affect the net charge of the peptide. On the other side, the switch at position 45 , which leads to the substitution between amino acid residues with different features, could have an influence on the protein structural characteristics and consequently on SBD2 function. The predictions from both packages demonstrated that the aforementioned substitution is not deleterious. Nevertheless the substitution does modify the net charge of the mutated protein (i.e., from a nonpolar amino acid to a polar one), and hence could affect its function. Some studies reported the existence of structure-function correlations [47] showing that small changes of the primary structure have an effect on their function [48-50]. However, further studies will be necessary to verify if these SNPs compromise SBD2 function.

The SNPs located in $3^{\prime}$-UTR were analyzed for their possible effect on the mRNA secondary structure. The results of this study demonstrated that the mRNA conformation in mutated condition of SBD1 was the same as in wild condition. Nevertheless, SBD2 structure changed in presence of mutations in the $3^{\prime}$-UTR both whether they were present in combination or not. The structural difference in SBD2 messenger may be related to a possible role of the SNPs in SBD2 mRNA translation efficiency and consequential modulation of protein production. The $3^{\prime}$-UTRs are indeed known to play crucial roles in the posttranscriptional processes including the modulation of the transport of mRNAs outside of the nucleus and of translation efficiency [51], the subcellular localization [52], and the stability [53]. Changes in the $3^{\prime}$-UTR sequences could alter the cis-acting regulatory elements, primary sequence 
motifs that bind to proteins leading to stabilization or destabilization of mRNAs or binding sites for microRNA, which are involved in post-transcriptional gene expression regulation mechanisms. The importance of UTRs in regulating gene expression is underlined by the finding that mutations altering UTRs can lead to pathology [54] and the effects caused by SNPs located within these regions were reported in different studies [55, 56]. Kalus et al. [40] have recently presented a study that correlates a $5^{\prime}$-UTR SNP ( $-44 \mathrm{C} / \mathrm{G} \mathrm{SNP}$ ) in the human DEFB1 gene with changes in the gene expression of two $\beta$-defensins: hBD- 1 and hBD-3, but this relationship was not observed when considering the peptide expression. They have proposed a post-transcriptional regulation of $D E F B 1$ through changes of mRNA secondary structure caused by the $5^{\prime}$-UTR SNP haplotypes. Other authors reported that the same SNP could change a putative NFKB binding site, proposing the influence of this polymorphism in the regulation of $D E F B 1$ gene expression at the transcription stage [57]. Moreover, a SNP in the $3^{\prime}-$ UTR of human DEFBI gene has been associated with the increased susceptibility to periodontal diseases and has been suggested to influence the microRNA regulation, probably modifying the putative $3^{\prime}$ binding site of a specific miRNA [58].

Given the relevance of the biological role of $\beta$-defensin peptides in the immune response, the SNPs identified in this study could therefore play a role in the modulation of the immune response against microbes, through increasing the antibacterial protein production, or sequence diversity, enhancing the pathogen recognition spectrum. Nevertheless, further studies are necessary to verify whether the mutations identified in the $3^{\prime}$-UTR affect the mRNA stability and the expression of these immunity genes.

Acknowledgments The authors would like to acknowledge the Ministero delle Politiche Agricole Alimentari e Forestali (MiPAAF) (D.M. 302/7303/05) and the Ministero dell'Istruzione, dell'Università e della Ricerca (project \#2007898KYN, PRIN 2007) for financial support for this research.

\section{References}

1. Yount NY, Wang MS, Yuan J, Banaiee N, Oullette AJ, Selsted ME (1995) Rat neutrophil defensins. Precursor structures and expression during neutrophilic myelopoiesis. J Immunol $155: 4476-4484$

2. Otvos LJr (2000) Antibacterial peptides isolated from insects. J Pept Sci 6:497-511

3. Thomma BPHJ, Cammue BPA, Thevissen K (2002) Plant defensins. Planta 216:193-202

4. Brogden KA, Ackermann M, McCray PBJr, Tack BF (2003) Antimicrobial peptides in animals and their role in host defences. Int J Antimicrob Ag 22:465-478

5. Lehrer RI (2004) Primate defensins. Nat Rev Microbiol 2:727-738
6. Lehrer RI, Ganz T (2002) Defensins of vertebrate animals. Curr Opin Immunol 14:96-102

7. Selsted ME, Ouellette A (2005) Mammalian defensins in the antimicrobial immune response. Nat Immunol 6:551-557

8. Kaiser V, Diamond G (2000) Expression of mammalian defensin genes. J Leukoc Biol 68:779-784

9. Yang D, Biragyn A, Kwak LW, Oppenheim JJ (2002) Mammalian defensins in immunity: more than just microbicidal. Trends Immunol 23:291-296

10. Sorensen OE, Cowland JB, Theilgaard-Mönch K, Liu L, Ganz T, Borregaard N (2003) Wound healing and expression of antimicrobial peptides/polypeptides in human keratinocytes, a consequence of common growth factors. J Immunol 170:5583-5589

11. Yang D, Chertov O, Bykovskaia SN, Chen Q, Buffo MJ, Shogan J, Anderson M, Schroder JM, Wang JM, Howard OM, Oppenheim JJ (1999) Beta-defensins: linking innate and adaptive immunity through dendritic and $\mathrm{T}$ cell CCR6. Science 286:525-528

12. Maxwell AI, Morrison GM, Dorin JR (2003) Rapid sequence divergence in mammalian $\beta$-defensins by adaptative evolution. Mol Immunol 40:413-421

13. Patil AA, Cai Y, Sang Y, Blecha F, Zhang G (2005) Crossspecies analysis of the mammalian $\beta$-defensin gene family: presence of syntenic gene clusters and preferential expression in the male reproductive tract. Physiol Genomics 23:5-17

14. Diamond G, Kaiser V, Rhodes J, Russell JP, Bevins CL (2000) Transcriptional regulation of $\beta$-defensin gene expression in tracheal epithelial cells. Infect Immun 68:113-119

15. Roosen S, Exner K, Paul S, Schroder JM, Kalm E, Looft C (2004) Bovine $\beta$-defensins: identification and characterization of novel bovine $\beta$-defensin genes and their expression in mammary gland tissue. Mamm Genome 15:834-842

16. Selsted ME, Tang YQ, Morris WL, McGuire PA, Novotny MJ, Smith W, Henschen AH, Cullor JS (1993) Purification, primary structures, and antibacterial activities of $\beta$-defensins, a new family of antimicrobial peptides from bovine neutrophils. J Biol Chem 268:6641-6648

17. Yount NY, Yuan J, Tarver A, Castro T, Diamond G, Tran PA, Leavy JN, McCullough C, Cullor JS, Bevins CL, Selsted ME (1999) Cloning and expression of bovine neutrophil $\beta$-defensins, biosynthetic profile during neutrophilic maturation and localization of mature peptide to novel cytoplasmic dense granules. J Biol Chem 274:26249-26258

18. Diamond G, Jones DE, Bevins CL (1993) Airway epithelial cells are the site of expression of a mammalian antimicrobial peptide gene. Proc Natl Acad Sci USA 90:4596-4600

19. Cormican P, Meade KG, Cahalane S, Narciandi F, Chapwanya A, Lloyd AT, O'Farrelly C (2008) Evolution, expression and effectiveness in a cluster of novel bovine beta-defensins. Immunogenet 60:147-156

20. Shi J, Zhang G, Wu H, Ross C, Blecha F, Ganz T (1999) Porcine epithelial $\beta$-defensin 1 is expressed in the dorsal tongue at antimicrobial concentrations. Infect Immun 67:3121-3127

21. Sang Y, Patil AA, Zhang G, Ross CR, Blecha F (2006) Bioinformatic and expression analysis of novel porcine $\beta$-defensins. Mamm Genome 17:332-339

22. Zhao C, Nguyen T, Liu L, Shamova O, Brodgen K, Lehrer RI (1999) Differential expression of caprine $\beta$ defensins in digestive and respiratory tissues. Infect Immun 67:6221-6224

23. Sharma A, Dev K, Kumar A (2006) Cloning and characterization of goat lingual antimicrobial peptide (Unpublished) (GenBank DQ836129)

24. Huttner KM, Lambeth MR, Burkin HR, Burkin DJ, Broad TE (1998) Localization and genomic organization of sheep antimicrobial peptide genes. Gene 206:85-91 
25. Luenser K, Fickel J, Ludwig A (2005) Evolution of caprine and ovine $\beta$-defensin genes. Immunogenet 57:487-498

26. Guimarães RL, Segat L, Rocha CRC, Brandão LAC, Zanin V, Araujo J, Naslavsky MS, de Lima Filho JL, Crovella S (2009) Functional polymorphisms of DEFB1 gene in type 1 diabetes Brazilian children. Autoimmun 42:406-413

27. Ricci E, Malacrida S, Zanchetta M, Montagna M, Giaquinto C, De Rossi A (2009) Role of beta-defensin-1 polymorphisms in mother-to-child transmission of HIV-1. J Acquir Immune Defic Syndr 51:13-19

28. Ryniewicz Z, Zwierzchowski L, Bagnicka E, Flisikowski K, Maj A, Krzyżewski J, Strzałkowska N (2003) Association of the polymorphism at defensin gene loci with dairy production traits and milk somatic cell count in Black-and-White cows. Anim Sci Pap Rep 21:209-222

29. Wojdak-Maksymiec K, Kmieć M, Żukiewicz A (2006) Associations between defensin polymorphism and somatic cell count in milk and milk utility traits in Jersey dairy cows. J Vet Med A 53:495-500

30. Bagnicka E, Strzalkowska N, Flisikowski K, Szreder T, Jozwik A, Prusak B, Krzyzewski J, Zwierzchowski L (2007) The polymorphism in the beta4-defensin gene and its association with production and somatic cell count in Holstein-Friesian cows. J Anim Breed Genet 124:150-156

31. Miller SA, Dykes DD, Polesky HF (1988) A simple salting out procedure for extracting DNA from human nucleated cells. Nucleic Acids Res 16:1215

32. Thompson JD, Higgins DG, Gibson TJ (1994) CLUSTAL W: improving the sensitivity of progressive multiple sequence alignment through sequence weighting, position-specific gap penalties and weight matrix choice. Nucleic Acids Res 22:4673-4680

33. Rousset F (2008) Genepop'007: a complete re-implementation of the Genepop software for Windows and Linux. Mol Ecol Resour 8:103-106

34. Thomas PD, Campbell MJ, Kejariwal A, Mi H, Karlak B, Daverman R, Diemer K, Muruganujan A, Narechania A (2003) PANTHER: a library of protein families and subfamilies indexed by function. Genome Res 13:2129-2141

35. Ng PC, Henikoff S (2003) SIFT: predicting amino acid changes that affect protein function. Nucleic Acids Res 31:3812-3814

36. Mathews DH, Disney MD, Childs JL, Schroeder SJ, Zuker M, Turner DH (2004) Incorporating chemical modification constraints into a dynamic programming algorithm for prediction of RNA secondary structure. Proc Natl Acad Sci USA 101:7287-7292

37. Bowdish DME, Davidson DJ, Scott MG, Hancock REW (2005) Immunomodulatory activities of small host defense peptides. Antimicrob Agents Chemother 49:1727-1732

38. Pazgier M, Prah A, Hoover DM, Lubkowski J (2006) Studies of the biological properties of human $\beta$-defensin 1 . J Biol Chem 282:1819-1829

39. Zou G, de Leeuw E, Li C, Pazgier M, Li C, Zeng P, Wei-Yue L, Lubkowski J, Lu W (2007) Toward understanding the cationicity of defensins arg and lys versus their noncoded analogs. J Biol Chem 282:19653-19665

40. Kalus AA, Fredericks LP, Hacker BM, Dommisch H, Presland RB, Kimball JR, Dale BA (2009) Association of a genetic polymorphism ( $-44 \mathrm{C} / \mathrm{G} \mathrm{SNP})$ in the human DEFB1 gene with expression and inducibility of multiple $\beta$-defensins in gingival keratinocytes. BMC Oral Health. doi:10.1186/1472-6831-9-21

41. Hafez EE, Abdel-Rahman SM, El-Sohaimy SA (2008) Accompaniment of the polymorphism at defensin gene loci with milk productivity in holstein friesian and egyptian cows. Biotechnol Anim Husb 24:9-21

42. Bergonier D, de Cremoux R, Rupp R, Lagriffoul G, Berthelot X (2003) Mastitis of dairy small ruminants. Vet Res 34:689-716

43. Cartegni L, Shern LC, Krainer AR (2002) Listening to silence and understanding nonsense: exonic mutations that affect splicing. Nat Rev 3:285-298

44. Chamary JV, Parmley JL, Hurst LD (2006) Hearing silence: nonneutral evolution at synonymous sites in mammals. Nat Rev Genet 7:98-108

45. Fujii G, Selsted ME, Eisenberg D (1993) Defensins promote fusion and lysis of negatively charged membranes. Protein Sci 2:1301-1312

46. Semple CAM, Rolfe M, Dorin JR (2003) Duplication and selection in the evolution of primate $\beta$-defensin genes. Genome Biol 4:R31.1-.11

47. Raj PA, Antonyraj KJ, Karunakaran T (2000) Large-scale synthesis and functional elements for the antimicrobial activity of defensins. Biochem J 347:633-641

48. Boniotto M, Antcheva N, Zelezetsky I, Tossi A, Palumbo V, Verga Falzacappa MV, Sgubin S, Braida L, Amoroso A, Crovella S (2003) A study of host defence peptide $\beta$-defensin 3 in primates. Biochem J 374:707-714

49. Klüver E, Schulz-Maronde S, Scheid S, Meyer B, Forssmann WG, Adermann K (2005) Structure-activity relation of human $\beta$ defensin 3: influence of disulfide bonds and cysteine substitution on antimicrobial activity and cytotoxicity. Biochemistry 44:9804-9816

50. Klüver E, Adermann K, Schulz A (2006) Synthesis and structureactivity relationship of $\beta$-defensins, multi-functional peptides of the immune system. J Pept Sci 12:243-257

51. van der Velden AW, Thomas AA (1999) The role of $5^{\prime}$ untraslated region of an mRNA in translation regulating during development. Int J Biochem Cell B 31:87-106

52. Jansen RP (2001) mRNA localization: message on the move. Nat Rev Mol Cell Biol 2:247-256

53. Bashirullah A, Cooperstock RL, Lipshitz HD (2001) Spatial and temporal control of RNA stability. Proc Natl Acad Sci USA 98:7025-7028

54. Conne B, Stuzt A, Vassalli JD (2000) The $3^{\prime}$ untraslated region of messenger RNA: a molecular 'hotspots' for pathology? Nat Med 6:637-641

55. Puga I, Lainez B, Fernandez-Real JM, Buxade M, Broch M, Vendrell J, Espel E (2005) A polymorphism in the $3^{\prime}$ untraslated region of the gene for tumor necrosis factor receptor 2 modulated reporter gene expression. Endocrinology 146:2210-2220

56. Wang J, Pitarque M, Ingelman-Sundberg M (2006) 3'-UTR polymorphism in the human CYP2A6 gene affect mRNA stability and enzyme expression. Biochem Biophys Res Commun 340:491-497

57. Prado-Montes de Oca E, Velarde-Felix JS, Rios-Tostado JJ, Picos-Cardenas VJ, Figuera LE (2009) SNP 668C (-44) alters a NF-kappaB1 putative binding site in non-coding strand of human beta-defensin 1 (DEFB1) and is associated with lepromatous leprosy. Infect Genet Evol 9:617-625

58. Schaefer AS, Richter GM, Nothnagel M, Laine ML, Rühling A, Schäfer C, Cordes N, Noack B, Folwaczny M, Glas J, Dörfer C, Dommisch H, Groessner-Schreiber B, Jepsen S, Loos BG, Schreiber S (2010) A 3' UTR transition within DEFB1 is associated with chronic and aggressive periodontitis. Genes Immun $11: 45-54$ 